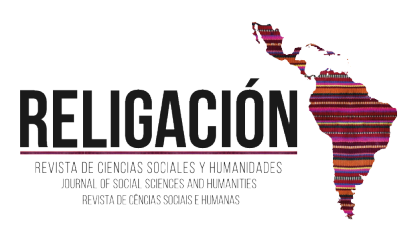

Sección General

\title{
In-house training for service company employees using information technology
}

Capacitación interna para empleados de empresas de servicios que utilizan tecnología de la información

\author{
Lubov K. Ilyashenko | Tyumen Industrial University - RUSSIA | \\ Industrial University of Tyumen, Surgut Branch, UI. Volodarskogo, 38, Surgut, 625000, Russia. E-mail: azshar2017@mail.ru \\ Zhanna V. Smirnova | Minin Nizhny Novgorod State Pedagogical University - RUSSIA | \\ Minin Nizhny Novgorod State Pedagogical UniversityNizhny, Novgorod, Russia E-mail: z.v.smirnova@mininuniver.ru \\ Olga I. Vaganova | Minin Nizhny Novgorod State Pedagogical University - RUSSIA | \\ Minin Nizhny Novgorod State Pedagogical UniversityNizhny, Novgorod, Russia \\ Svetlana N. Kaznacheeva | Minin Nizhny Novgorod State Pedagogical University - RUSSIA | \\ Minin Nizhny Novgorod State Pedagogical University, st Ulyanova 1, Nizhny Novgorod 603004, Russia E-mail: cnkaznacheeva@gmail.com \\ Natalia V. Bystrova | Minin Nizhny Novgorod State Pedagogical University - RUSSIA | \\ Minin State Pedagogical University of Nizhny Novgorod, 1, Ulyanova street, Nizhny Novgorod, 603005
}

\begin{abstract}
The article reveals the structure of the content of in-house training and retraining of employees, reflects the principles on which training is based and the functions that are performed by in-house professional training. Throughout the world and in Russia in particular, the subject of increased attention is the introduction of information technology. Therefore, the authors consider the in-house training of employees of the service company using the designated technologies. The agency Registration Agency, a limited liability company, was considered in the article. In 2018, among its employees, a survey was conducted that revealed the desire of employees to improve their skills through electronic courses provided by Nizhny Novgorod State Pedagogical University. It was attended by 30 respondents. After the meeting, employees were asked to undergo training on the organization of personal effectiveness. The training was conducted successfully and, based on the data obtained, we concluded that there is a need for further closer cooperation between organizations, therefore, we presented a plan of interaction between Nizhny Novgorod State Pedagogical University named after Kozma Minin and the Registration Agency limited liability company, the result of which in the future should be the achievement of benefits for both parties.
\end{abstract}

Keywords: service company, employees, higher education institution, students, information technology.

RESUMEN: El artículo revela la estructura del contenido de la capacitación interna y el reciclaje de los empleados, refleja los principios en los que se basa la capacitación y las funciones que realiza la capacitación profesional interna. En todo el mundo y en Rusia en particular, el tema de mayor atención es la introducción de la tecnología de la información. Por lo tanto, los autores consideran la capacitación interna de los empleados de la empresa de servicios utilizando las tecnologías designadas. La agencia, la Agencia de Registro, una compañía de responsabilidad limitada, fue considerada en el artículo. En 2018, entre sus empleados, se realizó una encuesta que reveló el deseo de los empleados de mejorar sus habilidades a través de cursos electrónicos proporcionados por la Universidad Pedagógica Estatal de Nizhny Novgorod. Asistieron 30 encuestados. Después de la reunión, se pidió a los empleados que recibieran capacitación sobre la organización de la efectividad personal. La capacitación se realizó con éxito y, en base a los datos obtenidos, concluimos que existe la necesidad de una cooperación más estrecha entre las organizaciones, por lo tanto, presentamos un plan de interacción entre la Universidad Pedagógica del Estado de Nizhny Novgorod, cuyo nombre es Kozma Minin y la Agencia de Registro limitada empresa de responsabilidad, cuyo resultado en el futuro debería ser el logro de beneficios para ambas partes.

Palabras clave: empresa de servicios, empleados, institución de educación superior, estudiantes, tecnología de la información. 


\section{INTRODUCTION}

The last few years, the service sector in Russia has been actively developing. The need of the society for services causes an increase in the service market. In this regard, the quality of service should remain at a high level and become better to maintain consumer demand. Therefore, in the article, the authors consider the topical issue of training employees of service enterprises. The main function of the service is to bring tangible and intangible benefits to citizens, as well as serving the consumption process and creating conditions for everyday life, recreation and leisure. That is, the scope of service covers a fairly extensive part of the life of the population. Therefore, the development of intra-company learning is so important (Pavlov, 2016). The success of the promotion of the organization's services is demanded by the consumer and, as a result, competitiveness depends on its level. Many scientists were engaged in the organization of training in the service sector. We can mention A.Ya. Kibanova, V.K. Romanovich, G.A. Avanesov, A.P. Ershov.

Every year, various institutions and organizations are trying to create and provide services of the most diverse kinds to the population (Nikolai, 2017a). Today, the service sector is a complex system consisting of enterprises of various forms of ownership, organizational and legal forms, which differ in purpose, scope of activity and composition of services provided (Nikolai, 2017b). Therefore, it seems to us that particularly important and necessary scientific understanding of this area in its cultural and economic content (Prokhorova, 2018). This task has become especially urgent for higher schools that train future graduates of the service sector (Skatova, 2018). Thanks to researchers, methodologists of higher educational institutions, the development of the problems of service activity, including its legal, substantive and managerial side, has achieved certain success (Perova, 2017).

However, in the practice of organizing the work of service enterprises, many unsolved problems remain (Vaganova, 2017b). Given the rapidly growing indicators of the role of the service sector in the gross domestic product of the country, it becomes clear that there is a huge potential in this area and the inevitability of its development. These trends lead to increased competition among service companies in this area and the need to use modern technologies to optimize the activities of service organizations (Vaganova, 2018).

One of the necessary conditions is the appeal of the subjects of service activities to information technologies that represent the broadest opportunities for improving the activities of organizations.

\section{LITERATURE REVIEW}

Information technology in higher education

Information technology is a major part of the education modernization process. This includes various devices and methods for processing information. First of all, these are computers with the necessary software and telecommunications along with the information placed on it. They make it possible to realize remote communication between teachers and students.

Information technologies with a constant increase in the volume of information flow are becoming more and more firmly fixed in the activities of educational organizations, including higher schools. Training highly qualified specialists of any field is impossible without their use. The service sector is one of the most developing and the activities of specialists in this field are directly related to information technology. Therefore, their development is one of the components of student success. The issues of the development of information technologies in higher education were studied by I. Robert, S.I. Goodilina, L.V. Krasovskaya, T.I. Isabekov, saying that the use of presentations, text editors, graphic packages and other information technology tools help to present materials in a more visual and convenient form, which allows to improve the process of learning and memorizing material, make it faster, which leads to increased learning performance.

In this paper, we will talk about company employees, that is, current professionals. And for them, this improvement (speed advantage) is extremely important due to employment. One of the most effective ways of teaching, in our opinion, are electronic courses, where students have the opportunity to use electronic textbooks, tests, presentations and many other tools that clearly provide information, in an accessible form, which the listener can perform at any convenient time convenient location.

\section{METHODOLOGY}

The Department of Service Technologies and Technological Education of the Minin Nizhny Novgorod State Pedagogical University has sufficient experience in preparing students in the direction of "Service". And for a long time, the university actively uses educational information technologies. This is enough to organize experimental work on the in-house professional training of employees of any organization using information technologies. For the 
intensification of the organization's activities through the integration of information technologies, the service company Limited Liability Agency "Registration Agency" was used. The study was applied survey method. In order to identify the predisposition of employees to training, a survey was conducted among the employees of this institution in 2018 "Would you like to improve your qualifications using the electronic educational environment?". It was attended by 30 people, 18 women and 12 men. After the survey, employees were offered a small training in electronic form "Time Management - Increasing Productivity", which was equipped with the necessary tools to develop the personal productivity of employees. For example, students were asked to perform an exercise in the framework of the training "A Minute to a Conversation". One participant per minute should tell another information on a given topic. Thus, all participants learn to express their thoughts in a short period of time. The results of the survey after the training showed a positive attitude of the employees of the "Registration Agency" organization to cooperation with the university.

In turn, the company provides an opportunity for university students to do internships within their walls. Thus, both parties benefit. The article presents a plan for the phased implementation of experimental activities.

\section{ANALYSIS AND DISCUSSION}

In-house employee training is an extremely important issue for virtually every working person in the country. Naturally, personnel training is based on special principles (Markova, 2018). There are quite a few of those, and researchers often have disagreements. However, highlighting the basic principles is a feasible task (Smirnova, 2017b). Any organizations, including service companies, use them (Myalkina, 2018). We have identified several of the following: reliability. This principle suggests that learning will take place regardless of any situational factors (Vaganova, 2017a); objectivity. Training takes place regardless of the views of employees and organizations as well as availability. The principle ensures that the learning process is understandable for all participants, both teachers and students (Bulaeva, 2018).

We also note that modern training within an organization should have elements that make employees aware of their personal goals and life values, as well as be able to create more creative thinking and management skills of various groups in size and character.

The structure of the content of training is usually distinguished: introductory training of new employees (general familiarity with the company); advanced training of all categories of workers (with varying degrees of training); retraining staff.

The development of the categories of competence of employees that meet the real needs of an organization (llyashenko, 2018d) distinguishes the development of those categories of competence from the entire volume of tasks that should be performed by in-house training. From this point of view, the professional development of personnel in an enterprise can be viewed as a set of activities aimed at improving the skills of workers (Garina, 2017).

In the structure of the enterprise, the training system is developed in accordance with the tasks and needs of the enterprise and is carried out in order to adapt the employee in the new department or in the new position. Intrafirm education preserves and transfers the values of the organization, general standards, approaches and regulations, supports the corporate strategy of the enterprise.

The development strategy of training in an enterprise is determined through the functions that are performed by intra-company professional training: the definition and analysis of the competencies required for service workers (Smirnova, 2018); identifying the most appropriate forms and methods of teaching (Garina, 2018); motivation of employees to apply knowledge gained in the course of training; evaluation of results (llyashenko, 2018c).

All the elements we have identified should be implemented using information technologies - an integral part of modern education and life in general (Ilyashenko, 2018a).

One of the important functions provided by information technologies is the possibility of organizing inhouse employee training through the development and implementation of electronic educational courses aimed at improving the skills of workers in the service sector and competitiveness of an organization (llyashenko, 2018b).

Therefore, one of the most important tasks of organizations of the service profile is the use of modern information technologies in a wide range of possibilities for their use.

The Department of Service Technologies and Technological Education of the Minin Nizhny Novgorod State Pedagogical University has accumulated a great deal of experience in preparing students in the direction of "Service" (Ivanova, 2017). And for a long time, the university has been actively using educational information technologies (Hamitowa, 2017). Therefore, we consider it expedient to choose a service company "Registration Agency" limited liability company as an experimental platform for the intensification of the organization's activities through the integration of 
information technologies (Kochetova, 2017). The experimental site, in turn, becomes the base of clinical practice for students of the Minin Nizhny Novgorod State Pedagogical University in the direction of "Service".

Among the employees in order to identify their predisposition to training, in 2018, a survey was conducted "Would you like to improve your qualifications with the help of electronic courses?" (The course is fully adapted to the needs of a particular organization). It was attended by 30 people, 18 women and 12 men. His results are presented in Figure 1.

\section{Yes not}

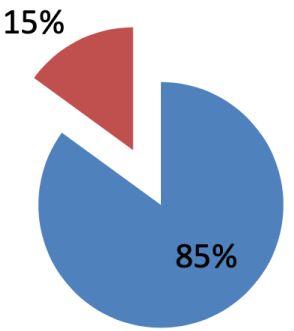

Figure 1. The results of a survey of employees of the service company "Registration Agency" in 2018

Most of the respondents agreed to improve their skills in electronic conditions (using an electronic course). It is really more convenient for them to study at a distance. While studying electronically, students have the opportunity at the same time to transfer their knowledge to the workflow within the company and quickly resolve emerging issues by contacting the teacher provided by the university.

After participating in the survey employees were offered a small training in electronic form "Time Management - Increasing Productivity", where they were able to get acquainted with the "Equalizer of Efficiency" model, master the rationality method in task management, the basic patterns of working with the "human factor" in the context of time management. Theoretical material with constant access, as well as special exercises, was provided for the listeners. For example

The task was successfully passed by the staff of the organization. They expressed their positive attitude to the further cooperation of the organizations. To identify this relationship, we conducted a survey "Would you like to continue training in the framework of cooperation with the university?" The composition and number of respondents did not change. The results are presented in Figure 2.

\section{Yes not}

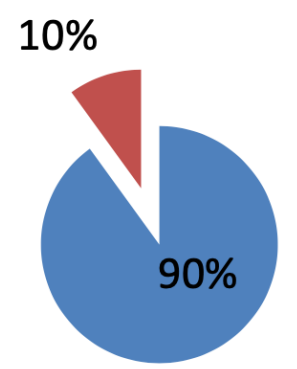

Figure 2. The results of a survey of employees of the service company "Registration Agency" on the topic "Would you like to continue training within the framework of cooperation with the university?"

After identifying a positive attitude to learning from the university, we proposed a plan for closer cooperation with the Registration Agency limited liability company.

The Department of Service Technologies and Technology Education is interested in translating the experience of introducing information technologies into the activities of a service organization and the practice of training future service workers (Chaikina, 2018). Such a practice-oriented inclusion of a student in the activities of an experimental site on the basis of a service enterprise opens up new opportunities for the formation of professional compe- 
tencies of future service professionals (Smirnova, 2017a). The stages of experimental activity are reflected in table 1.

Table 1. Plan for phased implementation of experimental activities.

\begin{tabular}{|c|c|c|}
\hline $\mathbf{N}$ & Experimental stage & THE MAIN ACTIVITY OF THE STAGE \\
\hline 11 & $\begin{array}{l}\text { Preparatory and } \\
\text { organizational stage }\end{array}$ & $\begin{array}{l}\text { 1. Theoretical substantiation of the relevance of the chosen topic, identification of a number of } \\
\text { problems, setting goals, tasks and identifying areas of joint activities of the Registration Agency } \\
\text { Limited Liability Company and the K. Minin Nizhny Novgorod State Pedagogical University. } \\
\text { 3. Creation of conditions for work on the chosen topic "Integration of information technologies } \\
\text { into the practice of service organizations". } \\
\text { 4. Resolving the issues of resource provision of the project: personnel, material, technical, fi- } \\
\text { nancial, methodological, informational. }\end{array}$ \\
\hline 22 & Pilot stage & $\begin{array}{l}\text { 1. Development of a package of proposals for the introduction of information and communica- } \\
\text { tion technologies in the organization. } \\
\text { 2. Implementation of project activities on the application of information technology in the } \\
\text { organization of service activities. } \\
\text { 3. Conducting scientific and educational seminars, workshops and consultations with teachers } \\
\text { of the department for employees of the organization on topical issues of education. } \\
\text { 4. Writing joint articles, participating in scientific conferences. }\end{array}$ \\
\hline 33 & $\begin{array}{l}\text { Summarizing } \\
\text { analytical stage }\end{array}$ & $\begin{array}{l}\text { 1. The introduction of information technology in the process of service enterprises. } \\
\text { 2. The process of formation of information and communication competence of the process } \\
\text { participants is provided. } \\
\text { 3. Corrective activities are carried out based on the results of the application of information } \\
\text { technologies in service activities. } \\
\text { 4. Synthesis and systematization of the work. }\end{array}$ \\
\hline
\end{tabular}

The result of the ongoing experimental activities on the integration of information technologies into service activities is an increase in the intensification of the organization's activities of the Registration Agency limited liability company and an increase in the effectiveness of training future graduates of the Service direction of Minin Nizhny Novgorod State Pedagogical University.

\section{CONCLUSION}

One of the most active ways to solve the problem of in-house training for service enterprise employees is the use of information technology. In the course of our work, we have achieved the goal we have set: building an experimental activity of an educational institution for in-house professional training of employees of an organization using information technologies. After conducting surveys among the employees of the Agency of Registration service enterprise, we firstly identified their positive attitude towards advanced training through e-learning, which is an effective tool for improving the skills of service workers and the organization's competitiveness (85\% of respondents wished to improve their skills) using the proposed electronic courses). The trial training in electronic form was successfully passed. And the staff of the agency "Registration Agency" agreed to further cooperation with the university $(90 \%$ of respondents want to continue training in the framework of cooperation with the university). Therefore, having identified a service company, the Registration Agency Limited Liability Company, as a base site, we developed a plan for the phased implementation of experimental activities. In turn, the organization provided an opportunity for students to do internships within its walls. Such a practice-oriented inclusion of a student in the activities of an experimental site on the basis of a service enterprise opens up new opportunities for the formation of professional competencies of future service professionals.

\section{BIBLIOGRAPHIC REFERENCES}

Bulaeva M.N., Vaganova O.I., \& Gladkova M.N. (2018). Activity technologies in a professional educational institution. Baltic Humanitarian Journal. 7. No.3 (24). pp. 167-170. https://elibrary.ru/item.asp?id=36237878 (in Russian).

Chaikina Z.V., Shevchenko S.M., Mukhina M.V., Katkova O.V., \& Kutepova L.I. (2018). Electronic testing as a tool for optimizing the process of control over the results of educational training activities. Popkova E.G. (ed.) The Impact of Information on Modern Humans. Springer. Vol. 622, pp. 194-200. https://doi.org/10.1007/978-3-319-75383-6_25

Garina, E., Kuznetsov, V., Yashin, S., \& et al. (2017). Management of Industrial Enterprise in Crisis with the Use of Incompany Reserve. Overcoming uncertainty of institutional environment as a tool of global crisis management: Conference on Overcoming Uncertainty of Institutional Environment as a Tool of Global Crisis Management Location: Athens, GREECE Date: APR, 2017. Book Series: Contributions to Economics. Pages: 549-555.

Garina, E.P., Garin, A.P., Kuznetsov, V.P., Popkova, E.G., \& Potashnik, Y.S. (2018). Comparison of approaches to development of industrial production in the context of the development of a complex product. Advances in Intelligent Systems and Computing, 622, pp. 422-431.DOI: 10.1007/978-3-319-75383-6_54

Hamitowa, S. M., Glinushkin, A. P., Avdeev, Y. M., \& et al. (2017). Condition Assessment of Tree Plantations and Phytosanitary Properties of Soils in Cedar Groves. International journal of pharmaceutical research and allied sciences. Volume: 6. Issue: 4. Pages: 1-7.

llyashenko L.K., Prokhorova M.P., Vaganova O.I., Smirnova Z.V., \& Aleshugina E.A. (2018a). Managerial preparation of engineers with 
eyes of students. International Journal of Mechanical Engineering and Technology (IJMET) Volume 9, Issue 4, April pp.10801087.

Ilyashenko, L.K., Smirnova, Z.V., Vaganova, O.I., Prokhorova, M.P., \& Abramova, N.S. (2018b). The role of network interaction in the professional training of future engineers(2018b) International Journal of Mechanical Engineering and Technology, 9 (4), pp. 1097-1105.

Ilyashenko, L.K., Vaganova, O.I., Smirnova, Z.V., Gruzdeva, M.L., \& Chanchina, A.V. (2018c). Structure and content of the electronic school-methodical complex on the discipline "mechanics of soils, foundations and foundations". International Journal of Mechanical Engineering and Technology, 9 (4), pp. 1088-1096.

Ilyashenko, L.K., Vaganova, O.I., Smirnova, Z.V., Sedykh, E.P., \& Shagalova, O.G. (2018d). Implementation of heurist training technology in the formation of future engineers (2018d) International Journal of Mechanical Engineering and Technology, 9 (4), pp. 1029-1035.

Ivanova, Svetlana S., Bystritskaya, Elena V., Burkhanova, Irina Y., \& et al. (2017). Physical Culture Teacher Professional Activity Problems in Polyethnic Educational Organization. Eurasian journal of analytical chemistry. Volume: 12. Issue: 7B. pp. 1615-1620.

Kochetova, E. V., Gutsu, E. G., Demeneva, N. N., \& et al. (2017). Psychological mechanisms of future pedagogues' professional individualization formation during their studies in a higher educational institution . Journal of fundamental and applied sciences. Volume: 9. Special Issue: SI. Supplement: 2. Pages: 1484-1493.

Markova S.M., \& Narcosiev, A. K. (2018). Professional education of vocational school students. Vestnik of Minin University. Vol. 6, no. 3. DOI: 10.26795/2307-1281-2018-6-3-3.

Myalkina E.V., Sedhyh E.P., Zhitkova V.A., Vaskina V.A., \& Isaykov O. I. (2018). University resource center as an element of social development of the region. Vestnik of Minin University. Vol. 6, no. 3. DOI: 10.26795/2307-1281-2018-6-3-1.

Nikolai, Fedor History, Archives, Studies of Memory: Disciplinary Politics and the Struggle for Authority . Novoe literaturnoe obozrenie. (2017a). Issue: 148. Pages: 321-326.

Nikolai, Fedor., \& Kobylin, Igor. (2017b). American trauma studies and the limits of their transitivity in Russia heart-to-heart talks with veterans of local conflicts. LOGOS. Issue: 5. Pages: 115-136.

Pavlov, A., Kindaev, A., Vinnikova, I., \& Kuznetsova, E. (2016). Crop insurance as a means of increasing efficiency of agricultural production in Russia. International Journal of Environmental and Science Education, 11(18), 11863-11868.

Perova, T. V., Kuznetsova, E. A., Vinnikova, I. S., Kaznacheeva, S. N., \& Chelnokova, E. A. (2017). Essence of the role and characteristics of the operating conditions of enterprises before and after the transition to market relations from a macroeconomic position. International Journal of Applied Business and Economic Research, 15(12), 103-112.

Prokhorova M.P., Semchenko A.A. Involving of trainees-future teachers of professional training in project activities in the discipline. Vestnik of Minin University. 2018. vol. 6, no. 2. p. 6. DOI: 10.26795/2307-1281-2018-6-2-6.

Skatova, A.A., Yambulatov, D. S., Fedyushkin, I. L., \& et al. (2018). Europium and Ytterbium Complexes with the Redox Active Acenaphthene-1,2-Diimine Ligand. Russian journal of coordination chemistry Volume: 44 Issue: 6 Pages: 400-409

Smirnova ZH.V., Gruzdeva M.L., \& Krasikova O.G. (2017a). Open electronic courses in the educational activities of the university. Vesknik of Minin University, no. 4(21), p. 3. https://doi.org/10.26795/2307-1281-2018-6-3-9 (in Russian).

Smirnova Zh.V., \& Krasikova O.G. (2018). Modern tools and technologies for assessing learning outcomes. Vestnik of Minin University. Vol. 6, no. 3. 9. DOI: $10.26795 / 2307-1281-2018-6-3-9$.

Smirnova ZH.V., Vaganova O.I., \& Trutanova A.V. (2017b). Final state certification as a way to comprehensive assessment of competences. Karelian Scientific Journal, vol. 6, no. 3(20), pp. 74-77., https://elibrary.ru/item.asp?id=30453035 (in Russian).

Vaganova O.I., Gladkov A.V., \& Trutanova A.V. (2017a). Formation of professional competencies of bachelors in the conditions of e-learning. Baltic Humanitarian Journal. vol. 6. no. 2 (19). pp. 190-193. https://elibrary.ru/item.asp?id=29415561 (in Russian).

Vaganova O.I., \& Ilyashenko L.K. (2018). The main directions of implementation technologies of student-centered education in high school. Vestnik of Minin University. vol. 6, no. 3. p.2 DOI: 10.26795/2307-1281-2018-6-3-2 (in Russian).

Vaganova O.I., Koldina M.I., \& Trutanova A.V. (2017b). Development of the content of vocational and pedagogical education in the context of the implementation of the competence approach. Baltic Humanitarian Journal. Vol. 6, no. 2(19), pp. $97-99$ (in Russian).

How to cite this article: llyashenko, L. K., Smirnova, Z. V., Vaganova, O. I., Kaznacheeva, S. N., \& Bystrova, N. V. (2020). In-house training for service company employees using information technology. Religación. Revista De Ciencias Sociales Y Humanidades, 5(23), 105-110. Retrieved from http://revista.religacion.com/index.php/religacion/article/view/603

Submitted: 11 December 2019 Accepted: 14 March 2020 Published: 31 March 2020

Religación. Revistais de Ciencias Sociales y Humanidades is a peer-reviewed open access journal published by CICSH-AL Centro de Investigaciones en Ciencias Sociales y Humanidades desde América Latina |Religación| 